\title{
Green economy: a role of IMC in formation of public consciousness
}

\author{
Emma Sharyan ${ }^{1,2, *}$, Irina Karimova ${ }^{1}$, and Elvina Bagdasarova ${ }^{3}$ \\ ${ }^{1}$ Moscow Polytechnic University, 38, B. Semenovskaya, 107023, Moscow, Russia \\ ${ }^{2}$ Moscow Region State University, Radio str, 10A, 105005, Moscow, Russia \\ ${ }^{3}$ Russian State Social University, 4, Wilhelm Pieck, 129226, Moscow, Russia
}

\begin{abstract}
The article considers the system-forming role of integrated marketing communications as a means of building a dialogue and finding a compromise between business, government and society. The impact of integrated communications on the formation of conscious consumption and care for environment in the countries of the world and in Russia has been estimated. The absence or insufficient efforts of the state to inform a consumer about environmental initiatives which form a negative or neglectful attitude to eco-activism as a whole have been revealed. Vice versa, carefully planned and purposeful actions to form introduce environmental initiatives and inform the target audience about them lead to a positive response from business and public, conscious adherence to established rules and regulations (separate collection of waste, reduction of consumption, saving of natural resources, saving production and etc.) and the formation of additional voluntary commitments and initiatives. As a result of the research, it was proposed to introduce the concept of re-use, reduce, recycle in Russia, both by companies and households.
\end{abstract}

\section{Introduction}

The main hypothesis of the study is that a competently and professionally built system of integrated marketing communications (abbr. IMC) makes a synergetic effect of joint efforts of the authorities, society and business in the formation of a "green economy". Russian and world practice shows that in this very sphere there are large reserves for the growth and development of public self-awareness and conscious following the environmental initiatives.

In modern economic and political practice the concept of "green economy" has become widely known and is used as one of the three concepts of global economic growth and development. According to the strategy of development, adopted by the United Nations, the concepts of CE (Circular Economy), GE (Green Economy) and BE (BioEconomy) have been adopted for the period up to 2030 (Agenda 2030, Sustainable Development Growth).

* Corresponding author: sharyan-emma@mail.ru 
Each of these concepts has its own direction and application and offers various solutions to achieve economic and social goals and preserve the environment.

The necessity to search solutions to environmental problems has been obvious for most of the population of the developed countries for more than a decade. The world community has been actively engaged in the development and financing the environmental programs in connection with the revision of the role of the influence of human activities on nature and its components since the middle of the second half of the last century.

We realize that it is extremely important to make changes in production methods to reduce pollution of the environment and the planet as a whole. This is directly related to the level of education and the general availability of information. But personal involvement in such processes of change still remains an implicit obligation for citizens in many countries.

We connect this state of matters with political situation in a number of countries which directly follows from the course of historical processes. Thus, Russia, being the successor of the state with a vast territory and ideology which was antagonistic to a capitalist society, undoubtedly requires its own approach to popularization the ideas of steady development, switching to renewable energy sources and processing of production waste.

Renewable energy generators require oil products for their production that can and should be done by countries with large oil reserves. New ways of recycling are constantly appearing. Their introduction can not only reduce costs but also do a real harm to nature. And here it is essential to outline the main task of social advertising when it comes to environmental protection.

\section{Materials and Methods}

In the article "Thinking green, circular or bio: Eliciting researchers' perspectives on sustainable economy with Q method" a leading scientist D.D.Amato points out: "CE draws on the ideas of industrial ecology and industrial metabolism, promotes reduction and efficiency in resource use, re-use and recycling of industrial outputs, and prolonging product life time. Engineering-driven innovation forms the foundation of such industrial changes, as identified in comprehensive literature reviews by Kirchherr et al., (2017); Prieto-Sandoval et al. (2018).Even though important components of GE include low carbon technology and resource efficiency (see definition by UNEP, 2011), its core elements consist of accounting, conservation and enhancement of multiple ecosystem services. The biosphere is thus seen as a fundamental matrix supporting human well-being (Gasparatos and Willis, 2015;ten Brink et al., 2012). Instead, the mainstream understanding of $\mathrm{BE}$ is that fossil-fuel-based industrial inputs should be replaced or complemented by renewable bio-based resources and materials. In this context, knowledge-based innovation and the use of biotechnology are key factors (Buggeet al., 2016; Pfau et al., 2014) [1]".

Many researchers, including the mentioned D. Amato, also tell about the convergence and complementarity of the above concepts as well as about different approaches to their application according to the state policy of a country: "All the three concepts are explicitly part of the policy debates and agenda setting processes at European Union (EU) level, with the action plan for the circular economy (EC, 2015), the green economy policy targets and objectives (EAA, 2013), and the bio-economy strategy (renewed in 2018) (EC, 2012,2018). The green economy, a concept driven by the United Nations (UNEP, 2011) is also reflected in the OECD green growth strategy (OECD, 2011).Bio economy policies are rather ubiquitous as well, despite different foci having been recorded across countries (Dietz et al., 2019). The circular economy has been particularly prominent in China, introduced through a national law (McDowall et al., 2017) [1]”.

It should be noted that, on the one hand, all the above-mentioned concepts adopted at the level of legislative initiatives and supported by public organizations (for example, 
separate collection of garbage, refusal to use plastic packaging, additional measures to reduce emissions into the environment) do serve to protect the environment. Table 1 summarizes the beginning of the practice of applying systematic waste sorting in Europe [2, 18-24]. On the other hand, it is an additional (and often very substantial!) financial burden for the business associated with the introduction of innovations, resource-saving technologies, the concept of safety manufacturing, etc. Nevertheless, companies do not only introduce new solutions but also initiate counter environmental initiatives and additional proposals.

Table1. The development of separate waste collection in Europe.

\begin{tabular}{|c|c|c|c|}
\hline № & A country & $\begin{array}{l}\text { The beginning of the } \\
\text { project }\end{array}$ & Application \\
\hline 1. & Germany & 1974 year & $\begin{array}{l}\text { the first containers for collecting glass appeared, } \\
\text { and since } 1978 \text { they introduced a multi-chamber } \\
\text { system for collecting garbage }\end{array}$ \\
\hline 2. & France & 1992 year & $\begin{array}{c}\text { a law was passed which obliged local authorities } \\
\text { to ensure household waste recycling; a separate } \\
\text { collection system was introduced }\end{array}$ \\
\hline 3. & United Kingdom & 1990 year & $\begin{array}{l}\text { the need for waste sorting was recorded in the } \\
\text { law on environmental protection }\end{array}$ \\
\hline 4. & Sweden & in the late $1990 \mathrm{~s}$ & $\begin{array}{l}\text { ubiquitous waste sorting was introduced } \\
\text { relatively European standards relatively late, but } \\
\text { now about } 50 \% \text { of waste is recycled in the } \\
\text { country, and the remaining half of the garbage is } \\
\text { still sent for incineration }\end{array}$ \\
\hline 5. & Poland & in the early 2010 s & $\begin{array}{c}\text { an active transition to the sorting and further } \\
\text { processing of waste began when the state } \\
\text { transferred the issue of municipal waste to local } \\
\text { authorities }\end{array}$ \\
\hline
\end{tabular}

So, one of the leaders of fashion industry, Inditex Group, has announced a complete transition of its brand Zara to eco-materials when creating its collections. Inditex Executive Director Pablo Isla and Marta Ortega, a daughter of the company's founder, reported about this initiative: "Today only $20 \%$ of the brand's collections are made of eco-friendly fabrics but by 2025 their number will have been $100 \%$ and the amount of harmful chemical elements will have been reduced to zero. The brand is reusing its cardboard boxes today and is developing a method of clothes rack recycling (the process of artificial decomposition and renewal of products). "We are always ready for innovations that will make us better, no matter if it is working with modern technologies and recycled materials or creating eco-fabrics of the future. This approach is correct not only from a commercial but also from a moral point of view," said Marta Ortega. By 2020, Inditex, the owner of Zara, will have fully refused plastic bags in stores of its brands, and by 2023 - from all disposable plastic items. The company's offices and stores will have gradually switched to energy consumption of renewable sources by 2025 with its share at least $80 \%$. Also, by this time, cotton and linen in the collections will have been organic, and polyester - recycled. Zara now has the Join Life line which is made of eco- friendly materials. It makes up $20 \%$ of the entire range of the brand. They are planning to increase its share to $25 \%$ next year [3]"'.

Sustainable shopping is supported by both retailers and developers.

While designing and constructing shopping centers developer companies actively use and improve green economy technologies, apply heat-saving technologies and materials, see the possibility to collect and use rainwater, install solar panels, reduce the use of plastic materials in interior decoration, design public spaces and landscapes so as to maximize the use of natural and recycled materials. One of the largest real estate retailers in the United 
States, Regency, supported by U.S. Green Building Council (USGBC) has developed and introduced the concept "LEED-certified shopping centers» and has reequipped over 100 of their real estate properties for the past few years [4].

It goes without saying that such business initiatives should be supported and approved as much as possible not only by a state, but also by a society. Previous practice and research show that consumers are "confident that companies should be accountable to society. Moreover, responsibility is understood first of all as a concern about social and ethical problems and environmental protection, including due to a decrease in the consumption of water, energy and resources.

Customers tend to choose responsible companies, particularly those that deal with "environmental issues" according to a study in Italy (Corporate Social Responsibility in the Perception of Purchasers (2013). But it was also noted that insufficient consumer awareness of measures taken by a state and business to preserve the environment leads to a misunderstanding that certain steps and actions are required to be taken by the population as well [5].

\section{Results and Discussion}

Work with public opinion should include not only raising public awareness of those measures that are being taken at a state level, creating approved patterns of behavior (saving natural resources, switching to separate waste collection, rejecting plastic packaging, etc.) but also specific actions to install different types of containers for different types of household waste, automatic machines for receiving plastic containers, etc.

The absence or lack of such opportunities negatively affects the involvement of the population, even profoundly informed one. It should be noted that environmental initiatives are perceived by consumers favorably but a lack of ability to support them with real actions leads to further negative perception of such information.

For Russia it is essential to take careful actions in all areas of the economy to follow the way of sustainable development. It requires a model of the organizational and economic mechanism that would provide the transition to a "green economy", reorientation of economic, environmental and social institutions to priority areas. There is an obvious urgent need for a transition to an economic model that will increase human well-being while preserving resources and not putting future generations at significant environmental risks" [6-17].

The authors of the article conducted a survey among students of the Moscow Polytechnic University in order to find out what a younger generation knows about the "green economy" and the actions that the population can take to form environmentally conscious behavior. It turned out that, on the whole, the awareness of young people about the need to take care of the environment, the actions of the state and business is quite high.

There is also a high level of awareness of the actions that they can take (separate collection of garbage, saving of resources, switching from plastic packaging to more environmentally friendly materials, purchasing clothes made of eco-friendly and recycled materials) but at the same time a lack of specific capabilities (containers for separate collection of garbage, etc.) hinders these initiatives.

However, it should be pointed out that it is the young generation that is an initiator who actively supports environmentally-oriented initiatives, including those that concern them directly.

Various answers have been received to the question about what can and should be done right now in your opinion:

- $\quad$ "The purpose of advertising programs and propaganda in this regard should be to attract people and their interests in the process of transition of the economy to a new stage. 
We need courageous, self-confident and capable of generating new solutions citizens. This is not a matter of preserving nature; it is a matter of improving living standards, social responsibility, self-awareness and self-importance".

- $\quad$ "You can start with simple issues, with separate collection of waste and garbage in particular. All the conditions for this are supplied in Moscow. Waste paper, plastic and glass are recycled, food waste is taken away for composting, and the rest, unsorted garbage is taken to landfills. Containers are provided for each type of waste in each yard and in many crowded spaces, for example, at the MCC stations or near the metro entrance, to realize this approach. Unfortunately, the information on the correct sorting of garbage at collection points is very scarce or so unsightly that we can assume that there isn't one (Fig. $1)$ ".

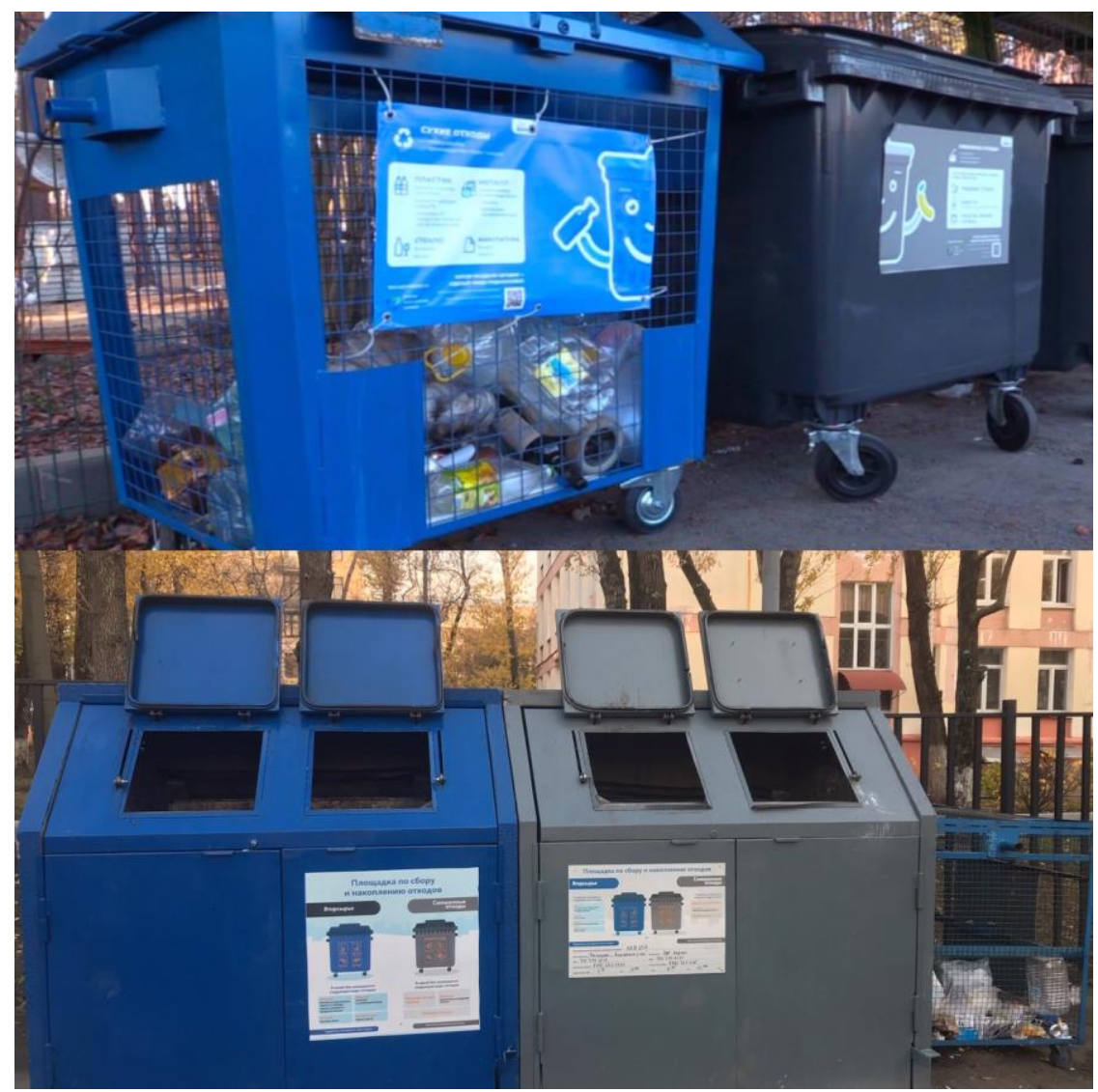

Fig. 1 Example of garbage sorting in Russia.

- $\quad$ "One is sure to say that Russia is taking great steps in the development of the Green Economy. A progress in the development and improvement of society on the territory of the country is also visible and that contributes to this development throughout the world. For the transition of Russia to the "green economy" it is necessary to carry out reforms in the social sphere of the country. Russia can reach a new economic level only through the interaction of citizens and the state".

The work with the most active part of the population (middle class, creative industries, managers), especially with youth, is the key to the success of environmental initiatives in the long term. 


\section{Conclusions}

Thus, the world and Russian practice of developing and supporting environmental initiatives which aims at creating public environmental self-awareness, introduction innovative resource-saving technologies and effective cooperation between government, business and society shows that it is impossible to achieve maximum effect without constant and focused informing of all participants of this process.

The system of integrated marketing communications, which combines the means of advertising, PR, GR and is actively used by companies in their activities, can be successfully used at the level of both state and business communities to create conscious consumption and concern for the environment in the countries of the world and in Russia in particular. The concept of "re-use, reduce, recycle", which has been successfully implemented and applied in the world by both companies and households and supported by public organizations and associations, has great prospects to be used in Russia in case all participants of the process are profoundly informed. The dialogue between authorities, business and society and joint efforts to preserve the environment is the key to the successful formation and development of a "green economy" and environmental selfawareness.

\section{References}

1. D. D'Amato, N. Droste, K.J. Winkler, A. Toppinen, J. of Clean. Prod. 230, 460-476 (2019) https://doi.org/10.1016/j.jclepro.2019.05.099

2. URL: https://www.kommersant.ru/doc/4004877

3. URL: https://fashionnet.ru/zara-polnostyu-perejdet-na-eko-proizvodstvo-k-2025-godu/

4. URL: http://plus.usgbc.org/sustainable-shopping/

5. URL: https://creativeconomy.ru/lib/4989

6. I.A. Rodionova, S.A. Lipina, Scie. J. Fund. Res. 2(24), 5462-5466 (2015)

7. I.M. Potravny, I.B. Gangut, A.L. Novoselov, Inst. of ec., Ur. Br. of the Russ. Ac. of Scie., 2, 438-450 (2016) DOI: 10.17059/2016-2-10

8. Z.O. Zhilbaev, L.V. Moiseeva, The Ed. and scie. J. 6(135), 62-74 (2016) DOI: 10.17853/1994-5639-2016-6-62-74

9. A.A. Grigoryan, Scie. Al., 5-1(19), 74-78 (2016) DOI: 10.17117/na.2016.05.01.074

10. G.A. Knyazeva, N.Y. Kirusheva, Bul. of St. Pet. Univ. Ec., 2, 119-145 (2016) DOI: $10.21638 / 11701 /$ spbu05.2016.207

11. I.V. Tsvetkova, Vector of science of the Tolyatti state University, Ser. Ec. and Man. 2 (33), 49-55 (2018) DOI: 10.18323/2221-5689-2018-2-49-55

12. Z.G. Mirzekhanova, Reg. ec.: Theor. and Pract. 16(6), 1082-1096 (2018) DOI: $10.24891 /$ re.16.6.1082

13. I.P. Glazyrina, I.A. Zabelina, Geog. and Nat. Res., 39(2), 103-110 (2018) DOI: 10.21782/GIPR0206-1619-2018-2(14-22)

14. D.N. Mukhlynin, Law and right, 6, 97-99 (2018) DOI: 10.24411/2073-3313-201810023

15. N.A. Vukovich, V.A. Larionova, V.V. Birulina, ARS ADMIN. Art of Man., 10(2), 257-271 (2018) DOI: 10.17072/2218-9173-2018-1-257-271

16. E.A. Voikina, I.M. Potravny, Vestnik of St. Pet. Univ.. Ec., 34(2), 217-240 (2018) DOI: $10.21638 / 11701 /$ spbu05.2018.202217 
17. N.A. Vukovic, Bul. of Ur. Fed. Univ. Ser. Ec. and Man., 17(1), 128-145 (2018) DOI: 10.15826/vestnik.2018.17.1.006

18. M.G. Girich, A.D. Levashenko, Int. trade and trade pol., 1 (17), $72-84$ (2019) DOI: 10.21686/2410-7395-2019-1-72-84

19. S. Kaplina, M. Semenova,, I., Kamanina, Mos. Reg. St. Univ. Ser.: Nat. scie., 2, 51-58 (2018) DOI: 10.18384/2310-7189-2018-2-51-58

20. K.A. Nazarova, E.A. Arustamov, Russ. J. of res., conser. and rec., 4, 1-10 (2017) DOI: 10.15862/10RRO417

21. E.D. Averianova, E.A. Arustamov, Russ. J. of res., conser. and rec., 4(2), 1-6 (2017) DOI: $10.15862 / 03 R R O 217$

22. A.Y. Verenikina, E.Y. Gorokhova, RUSS. ENT., 17(7), 901-918 (2016) DOI: 10.18334/rp.17.7.35091

23. E. Prelikova, V. Yushin, Y. Vyertakova, FOREST. MAG., 1 (33), 187-195 (2019) DOI: 10.12737/article_5c92017294e4b5.84748067

24. V.A. Marev, F.F. Gaev, S.I. Shkanov, A.M. Yakushina, M.L. Rakhmanov, E.G. Velichko, V.V. Yushin, S.A. Vahrushev, E.S. Tskhovrebov, Vestnik MGSU 1 (124), 46-59 (2019) DOI: 10.22227/1997-0935.2019.1.46-59 